Studying Meritocracy in an Unequal Context: Perspectives from Chilean Scholars

Jorge Atria, Juan Carlos Castillo, Luis Maldonado \& Luis Maldonado

Pp. 127 - 145

\title{
STUDYING MERITOCRACY IN AN UNEQUAL CONTEXT: PERSPECTIVES FROM CHILEAN SCHOLARS
}

\author{
Estudiando la meritocracia en un contexto desigual: perspectivas de \\ académicos chilenos
}

\begin{abstract}
Although the idea of meritocracy is widely present in social research, few studies analyze and discuss this concept. This research note shows the results from a first stage of a wider research project on meritocracy and distributive preferences in Chile, which is based on 9 interviews with social science scholars whose research is related to these issues. Findings show that researchers refer to merit and meritocracy not only departing from different definitions but also giving them contentious social relevance. Furthermore, effort takes precedence over talent, a more developed dimension in international research. The results are discussed taking the Chilean socio-cultural context into account, characterized by rapid neoliberal modernization as well as high economic inequality.
\end{abstract}

Keywords: meritocracy, social sciences, scholars, neoliberalism, Chile.

\section{UNIVERSUM \\ Revista de Humanidades y Ciencias Sociale}

\section{JORGE ATRIA}

Escuela de Sociología, Universidad Diego Portales; Centro de Estudios de Conflicto y Cohesión Social (COES). Correo electrónico: jorge. atria@mail.udp.cl

\section{JUAN CARLOS \\ CASTILLO}

Departamento de Sociología, Facultad de Ciencias Sociales, Universidad de Chile; Centro de Estudios de Conflicto y Cohesión Social (COES). Correo electrónico: juancastillov@uchile.cl

\section{LUIS MALDONADO}

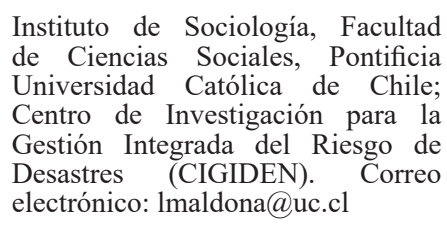

\section{SIMÓN RAMÍREZ}

Instituto de Sociología, Facultad
de Ciencias Sociales, Pontificia
Universidad Católica de Chile.
Correo electrónico:
ramirezg@gmail.com simon.

Artículo recibido el 20 de noviembre de 2018.

Aceptado el 10 de junio de 2019. 


\section{RESUMEN}

Aunque la idea de meritocracia tiene gran presencia en la investigación social, pocos estudios analizan y discuten este concepto. Esta nota de investigación expone los resultados de la primera etapa de un proyecto más amplio sobre meritocracia y preferencias redistributivas en Chile, con base en 9 entrevistas realizadas a académicos de ciencias sociales cuya investigación se relaciona con estos temas. Los resultados muestran que los expertos refieren al mérito y la meritocracia no solo utilizando distintas definiciones, sino también otorgándole distinta relevancia social. Asimismo, el esfuerzo adquiere mayor valoración que el talento, que inversamente aparece más desarrollado en la literatura internacional. Los resultados son discutidos considerando el contexto socio-cultural chileno, caracterizado por una rápida modernización neoliberal y una alta desigualdad económica.

Palabras claves: meritocracia, ciencias sociales, académicos, neoliberalismo, Chile.

\section{ACKNOWLEDGMENT}

The authors thank María Olivia Riquelme and Felipe Águila for their assistance with the project and participants at the 2017 COES Conference (Universidad Adolfo Ibáñez, Viña del Mar, Chile).

\section{FUNDING}

The research for this note was supported by the Chilean Sciences and Technology National Council (CONICYT) under Grant number 1160921. Jorge Atria and Juan Carlos Castillo thank the support by the Centre for Social Conflict and Cohesion Studies (COES, Conicyt/Fondap-15130009). Luis Maldonado thank the support by the National Research Center for Integrated Disaster Risk Management (CIGIDEN, Conicyt/ Fondap-15110017). 


\section{INTRODUCTION}

What is meritocracy and how to study it? Although the concept of meritocracy is widely present in the social science literature since its first appearance in Michael Young's The Rise of Meritocracy (1958), so far there are few studies particularly analyzing its definition and social relevance.

Meritocracy is a concept with a strong normative connotation both in academia and the public sphere. In general, the term meritocracy is used to represent a social order in which merit operates as a distributive criterion, that is, in which there is an alignment between performance and achievement. However, a review of literature suggests limited clarity regarding a more precise definition of what merit and meritocracy constitute.

This research note aims to contribute to a better understanding of the varying meanings and scopes of merit and meritocracy from the perspective of scholars. It takes into consideration both positive and negative beliefs, as well as disciplinary backgrounds, which provide different research approaches. To do this, 9 interviews with experts from the disciplines of sociology, economics, education and psychology were conducted, as part of a wider research project on meritocracy and distributive preferences in Chile. Since the interviews sought to draw on expert knowledge, the selection of interviewees was primarily based on their research experience on merit and meritocracy, though two additional criteria were used: gender and disciplinary diversity.

Findings show that merit and meritocracy do not have a single definition and such different notions involve particular values and public policy requirements. Furthermore, the inverted relevance given to the dimensions of merit with respect to international debates in literature is striking. While the latter has emphasized talent, Chilean researchers focus on effort, mainly due to the random distribution of talent and the effects of high inequality on individual achievement. In regard to beliefs of meritocracy, a broad variety of views and nuances ranges from skeptical positions to those that place it as a social ideal. However, there is a consensus regarding the absence of a meritocratic system in Chile, which is associated with inequality and the 
concentration of privileges and differ from the high valuation meritocracy has in Chilean society (UNDP, 2017).

In general terms, this approach contributes, firstly, to the exploration of the theoretical and empirical basis of inequality and social mobility analysis, as debates on merit and meritocracy put into play different views on distributive justice, individual abilities, and social ideals (Daniels, 1978). In Latin America, this includes questions on power and the social hierarchies underlying the uneven access to goods and services (Reygadas, 2008), inequality of opportunity in education (Reimers, 2000), or the extension of social citizenship (Pérez Sáinz, 2014). Secondly, it allows to understand different policy implications of the meritocratic principle. In Latin American countries, most research on these issues has concerned the implementation of meritocracy in organizations and reward systems (Barbosa, 2014; Di Caudo, 2016; Iacoviello \& Strazza, 2011; Parrado \& Salvador, 2011). The results of this paper recall the relevance of clarifying the aims and motivations behind public policies aimed at achieving meritocracy in key spheres of society.

The remaining of this research note is organized as follows. In the next section, a theoretical overview on merit, meritocracy and the Chilean case is presented, which is followed by section three where the methodological approach is introduced. The findings of this note are shown in section four, while section five concludes with final considerations and suggestions for future research.

\section{MERIT AND MERITOCRACY IN LITERATURE}

The seminal work in the study of meritocracy is Michael Young's 1958 satiric novel The Rise of Meritocracy, in which he argues that meritocracy refers to the social order in which rewards are exclusively associated with individuals" excellence under the idea of "merit". The latter is understood as the sum of intelligence and personal effort (Young, 1958). A meritocratic order would thus be opposed to any regime in which selection is based on ascribed characteristics such as gender, family background or race, among others 
(Miller, 1999). The meritocratic order thus seeks to ensure equal conditions based exclusively on personal merit for the allocation of social rewards (Breen \& Goldthorpe, 1999; Saunders, 1995; Young, 1958). Assuming that there are original differences between individuals in terms of capacity and dissimilar levels of effort and motivation, a meritocratic social structure should reflect such differences in relation to the merit achieved.

The above suggests that one element to consider is the extension of merit as a criterion for justification of social inequalities. An extensive validation of merit implies that it could represent a fundamental principle of ethical legitimation of the class system in capitalist societies (Bell, 1974) by simultaneously involving equality of opportunity and inequality of results (Miller, 1999). As a consequence, it can operate as a catalyst of demands for greater equality and as a mechanism for stigmatizing those who did not progress, hiding or justifying the structural causes of inequality (UNDP, 2017; Rosanvallon, 2013).

A major part of literature has preserved Young's seminal definition (1958) together with the dimensions of talent and effort (Breen \& Goldthorpe, 1999; Miller, 1999). However, the first component, which is associated with individual capacities, tends to receive more attention than the latter. Despite being part of the definition, effort has been subject of less reflection and study. In addition, various contemporary studies have identified problems with appealing to merit, among them the lack of consideration of contextual factors (Land, 2006) and its real usefulness for observing contemporary societies, due to the differences with those that Young observed (Arrow, Bowles, \& Durlauf, 2000).

The study of meritocracy from a sociological perspective has been traditionally characterized by a critical approach that describes the reproduction of social status and a lack of intergenerational mobility, usually interpreted as a failure in achieving one of the key promises of modernity (Alon \& Tienda, 2007; Duru-Bellat \& Tenret, 2012; Goldthorpe, 2003). In this case, meritocracy appears as an auxiliary concept that helps characterizing a given society. In contrast, we follow a different approach, which deals with 
the formation of social meanings of meritocracy in social groups and societies. This perspective, associated with the concept of moral economy, highlights the importance of shared cultural norms on relations of exchange and distribution (Mau, 2003). Those norms cannot be fully understood based on the perspective of rational choice, which has dominated studies on redistributive preferences (Sachweh, 2012). In this sense, a moral economy approach focuses on moral norms and feelings that structure and influence formal and informal economic practices (Thompson, 1971; Bowles, 1998), as well as cultural processes that can influence the production and reproduction of inequality (Lamont, Beljean, \& Clair, 2014)

This perspective constitutes an innovative starting point for addressing meritocracy in current society. By giving centrality to the perceptions, beliefs and values that sustain its relevance as a social criterion and that are at the basis of economic phenomena and institutional arrangements, qualitative evidence can be produced in an area in which empirical development has been especially quantitative (Son Hing et al., 2011; Likki \& Staerklé, 2015).

Finally, the study of meritocratic beliefs and perceptions from a moral economy perspective also allows to pose questions about preferences for redistribution. While one may expect to find a certain level of international consensus on the role of merit for justifying the allocation of high-status positions and/or income levels, it is not clear which concrete mechanisms meritocracy should establish to be understood as a fair distributive criterion. This deficit in the empirical literature is particularly visible regarding middle and low income countries. As a general hypothesis, if most people in a given society perceive performance as a central element for evaluating a fair allocation of social benefits, they should value public policies that privilege individual contributions --such as individual capitalization pension schemes or private healthcare systems-- to a greater extent than redistributive programs.

Chile represents an interesting case to examine these issues, as high support for meritocratic principles coexists with high levels of inequality and hoarding of advantages and opportunities (Guzmán, Barozet, \& Méndez, 2017) in a context of rapid neoliberal modernization. All of this influences individual 
and collective experiences and shapes patterns of mobility and class practices (Méndez \& Gayo, 2007; 2018; Araujo \& Martuccelli, 2014; UNDP, 2017).

After the massive social mobilizations of 2011, which brought to the street thousands of Chilean students against the educational system and the government (Somma, 2012) and included subsequently several political and social actors, the prevailing distributive paradigm and the role of state in providing social services were strongly criticized (Atria, 2018). These protests not only actively involved the use of both the virtual and physical public spaces (Cabalin, 2014), but also implied rethinking the limits of market and privatization and analyzing the effects of neoliberal reforms. In this sense, the Chilean case should shed light on the ways the meritocratic principle is understood and applied in unequal societies both from the perspective of scholars --as this research note aims to do-- and lay people in general.

\section{METHODOLOGY}

This research note presents the initial findings of a qualitative study as part of a broader empirical design which includes the application of different qualitative and quantitative techniques to social groups within the Chilean population. In this note, we explore the state of social research on meritocracy in Chile based on interviews conducted with experts from different disciplines in the social sciences. In that sense, this work only examines the academic field, that is, it is based on the analysis of perceptions and beliefs of scholars who were chosen to be representative of scientific knowledge associated with merit and meritocracy. As such, scholars' views leave out of consideration laypeople's conceptions of merit and meritocracy, as well as their everyday experiences. In this sense, we aim to understand how researchers approach this issue, which framework they use, and to what extent they differ when thinking of meritocracy as a social criterion. Consequently, our results inform about the use and evaluation of the meritocratic principle from a very specific point of view, in order to briefly present its main debates and illuminate some 
challenges to develop a systematic research agenda.

Interviews with experts allow information to be obtained from individuals with a high level of specific knowledge about issues of social interest (Bogner \& Menz, 2005). In this case, the experts' views help to understand the progress made in this field, positioning them as catalysts, by reducing the initial observation and assessment process and facilitating the identification of challenges to expand the research program into the future (Bogner \& Menz, 2005). In addition, the empirical work contributes to the reflexivity of the scientific system (Bourdieu \& Wacquant, 2005) by providing guidance about that which has already been developed in this area. This facilitates the understanding of the conditions under which scientific knowledge about merit and meritocracy has been produced, including the views of researchers and their ways of approaching the social reality (Mauthner \& Doucet, 2003; Bourdieu, 2004).

Following this approach, nine in-depth interviews were conducted with experts on the topics of merit and meritocracy using a theoretical sampling (Flores, 2009). The criteria used for the selection of interviewees were (i) published works that contribute to the study of merit and meritocracy in different social areas, (ii) gender, and (iii) disciplinary diversity. Such criteria were chosen to provide as much representativeness as possible to researchers from different institutions, sensibilities and methodological approaches. One foreign researcher whose work on merit and meritocracy has been developed on a broader level was added to the sample, given the international relevance of his works on these issues as well as his deep knowledge of Chilean society. During the interviews, suggestions were made by the researchers regarding other experts who could be contacted, until we reached a total of nine. Research employing qualitative methods to deal with specialists or experts' perceptions have used similar sample sizes (Milner \& Howard, 2004; Telg, 1996; Otero, 
2017; Rojas, 2008).

TABLE 1: Summary of Information on Experts Interviewed

\begin{tabular}{|ll|l|l|}
\hline Respondent & Gender & Discipline & Type of Institution \\
\hline E1 & Male & Economics & Private \\
\hline E2 & Male & Economics & Public \\
\hline E3 & Male & Psychology & Private \\
\hline E4 & Female & Sociology & Public \\
\hline E5 & Male & Sociology & Public \\
\hline E6 & Male & Economics & Public \\
\hline E7 & Female & Sociology & Public/Private \\
\hline E8 & Female & Sociology & Private \\
\hline E9 & Male & Education & Private \\
\hline
\end{tabular}

\section{RESEARCH ON MERITOCRACY IN CHILE}

\section{ON THE CONCEPT OF MERITOCRACY}

The researchers' findings and their analysis of the current state and evaluation of merit and meritocracy in Chilean society reveal that, in line with international academic debate, these are concepts that do not have one single meaning. Beyond more or less precise definitions, it is interesting that even the two components highlighted by literature do not always acquire the same importance. In general, while it is assumed that meritocracy is a system in which factors external to individuals are left aside, this does not always lead to a specific definition of what is or not meritorious and what the main sources of deservingness are. This is reinforced when the measurement of merit and meritocracy is considered: while some researchers are skeptical as to whether one can measure merit in general, or at the national level, others focus on the need for theoretical and conceptual clarifications as a prerequisite, which limits the formulation of more specific methodological designs.

Scholars recognize that merit and meritocracy are part of a very extensive social story. However, there is no consensus either on the support 
for this discourse or its foundations. For instance, one respondent emphasizes the significant rootedness of the meritocratic discourse in Chile: "We've been told a story about the topic, equality of opportunity, social mobility. It is rooted here... So people understand it, believe it and have faith in that story" (E2). For another interviewee, though it is clear that it is an expanded narrative, its aim seems to be the legitimization of inequalities: "These discourses are functional because they allow to capture the most talented people from lower income sectors... They are discourses that legitimate the inequality in the elite" (E4). In this sense, a certain alignment with the conceptual skepticism expressed by literature is observed.

Secondly, and without contradicting this low conceptual specification, effort acquires prominence in the characterization of merit. According to Young (1958), effort only represents one of the two main dimensions. For Chilean researchers, however, talent is overlooked or seems to be a subordinate dimension for two reasons. The first is its arbitrary nature. As one respondent stated, "Talent is the result of chance, and chance isn't fair" (E7). Another interviewee highlights the importance of the social circumstances that condition the development of talent:

The talent acquired is very much forged by affection, concern, the attention of your parents from the time you are born, and it is not under your control. As such, not considering the way in which the talent acquired was given to you.... and it was not under your control... It does not seem meritocratic to believe that talent is at play (E9).

A second reason for the subordination of talent to effort has to do with the particularly unequal structure of Chilean society. For several participants, high inequality reinforces the injustice of a random regime of talent distribution, as a majority group of people who have innate talents will not have the opportunity to develop them as a result of great asymmetries in the social hierarchy.

Effort is understood as an element that can generate a difference regarding the conditions that were originally given. The meanings highlighted by experts emphasize this dimension by referring to lower socio-economic 
sectors given that there is greater pressure on them in the context of high and persistent inequalities: "In order to be treated as an equal, he actually has to make much more of an effort (...) the effort required to come from a much more difficult place must be recognized" (E8). For another respondent, the social structure would establish a limit to effort, again stressing the importance of social circumstances for providing benefits or disadvantages to individuals:

This speaks to a giant disproportion regarding the initial conditions, so will it be true that kids who went to public school will have fewer synaptic connections than others? Probably not. And will they make less of an effort? Probably not. It is an average. Contextual conditions make the results very difficult. So, it is not evident that merit is there... At the end of the day, the person who goes further or the person who does not change...that may be conditioned by elements of context (E2).

The position of the researchers regarding effort and talent in Chile poses the question of whether a meritocratic system that solely promotes equality of opportunity in a context of such marked socio-economic differences is truly desirable. The answer brings us to the second point to be analyzed, which is related to beliefs in merit.

\section{BELIEFS IN MERIT AND MERITOCRACY}

Beliefs in meritocracy raised by the scholars interviewed move in an axis that ranges from skeptical positions to more accommodating ones. Table 2 presents both extremes and refers to their limitations, how they can operate in daily life, and their aspirations as social principles.

From a position closer to the first view, one researcher highlights the fictitious nature of meritocracy, assuming that the possibility of making conditions of origin equal is hardly possible. From there it follows that merit as a differentiable quality does not exist, working in everyday life as mechanism of social integration which confers order and provides expectations of progress and social mobility. Experts who share a more critical vision of meritocracy highlight the decisive influence of unequal contexts and ascribed factors (place of birth, last name, and inherited wealth) on the differentiated paths 
of individual development that Chilean society portrays. The relationship between meritocracy and equality of opportunity is also criticized, either because it is sustained on the basis of a social narrative that does not truly exist or it reveals a conservative model linked to the stability of original positions: "Women are women, workers are workers, rural dwellers are rural dwellers, the bourgeoisie are the bourgeoisie. No. You aren't really going to have a dream of... blending..." (E5). These critical views suggest that a realistic aspiration should be the expansion of positive discrimination, embodied by affirmative action policies that compensate for undeserved disadvantages and favor inclusion in key social areas.

TABLE 2: Beliefs in Meritocracy

Beliefs in Meritocracy

\begin{tabular}{llll}
\hline \multicolumn{1}{c}{ View } & \multicolumn{1}{c}{ Limitation } & \multicolumn{1}{c}{ Reality } & Desirable Goal \\
\hline $\begin{array}{l}\text { Meritocracy as } \\
\text { fiction }\end{array}$ & $\begin{array}{l}\text { Extremely unequal social } \\
\text { structure (influence of } \\
\text { origin, last names, etc.) }\end{array}$ & $\begin{array}{l}\text { Mechanism of social cohesion } \\
\text { (order) }\end{array}$ & Positive discrimination \\
$\begin{array}{l}\text { Meritocracy as } \\
\text { ideal }\end{array}$ & $\begin{array}{l}\text { High concentration of } \\
\text { privileges and rewards }\end{array}$ & $\begin{array}{l}\text { Only legitimate differences } \\
\text { remain, which cannot be } \\
\text { attributed to social class }\end{array}$ & $\begin{array}{l}\text { Mobile society that offers } \\
\text { incentives (social benefits) } \\
\text { based on merits }\end{array}$ \\
\hline
\end{tabular}

The other position sees meritocracy as a desirable and possible horizon. Experts with similar ideas share a negative evaluation of Chilean society, but have a more positive view of the possibility of moving towards the decentralization of privileges and rewards. When privileges are very concentrated, they end up offering social rewards to very small, predefined groups while making the dimensions of merit -effort and talent- irrelevant. In this sense, higher equality of opportunity should involve a more diversified allocation of social benefits. Considering the most recent evidence on wealth concentration (Flores et al, 2019) and the polarization of extremes within the Chilean income distribution (UNDP, 2017), this seems to be a complex 
challenge for the future.

Understood in this way, social life could hardly be absent from individual differences, but greater control of the current concentration of privilege should lead to progress in their social legitimacy. As one researcher puts it, "[The observable differences] will be legitimate if and only if everyone has certain basic conditions in which... they are not explained by social class" (E9), alluding to the influence of context on individual achievement. This is coherent with the assumption that meritocracy can favor equality of opportunity but definitively not that of results (Miller, 1999). The aspirations of a meritocratic society are thus observed in association with the idea of a dynamic society, in which it is desirable that higher and lower positions are potentially to be occupied by all individuals across different generations:

When you talk about a meritocratic society, you are also talking about a mobile society, because there is no guarantee that the child of a person who has merit will have merit... and what society supposedly does is generate a system of incentives that controls this a bit and tells you, 'Ok, this guy made an effort. Reward him. This guy didn't. Don’t reward him as much, or maybe punish him.' (E1).

Despite these different points of view, experts agree that high levels of inequality represent a clear obstacle to think of a meritocratic system. This is directly related to the introduction of normative criteria in the operation of the economy and citizens' redistributive preferences, which in turn indicates the pertinence of a moral economy approach: if meritocracy represents a social ideal, it should be reflected in public policies that allow for it, facilitating equality of opportunity and strongly limiting privileges. However, it is not clear to what extent a meritocratic system of public policies can promote social mobility while providing basic options of dignity and wellbeing to those who do not have socially required indicators of merit.

The challenge of implementing the principle of merit at the institutional level, then, lies in favoring a meritocratic performance, which implies tackling inequality, but without creating new disparities. In any case, most experts suggest that current institutional performance may reproduce inequalities. 
The education system appears as an eloquent example: "You have this social mobility mechanism, but it is also a mechanism for creating inequality" (E1); "The second one [which goes against meritocracy is] an educational system that does not question what does it mean to provide equal opportunity" (E3).

\section{FINAL CONSIDERATIONS}

The findings derived from the analysis of interviews with experts who have conducted research on merit and meritocracy reveal some key elements that shed light on fundamental discussions in this agenda.

Firstly, regarding the academic field, which our interviews allow to examine, it is clear that the principle of merit represents a relevant issue for most of the researchers. Nonetheless, a more developed conceptualization of its dimensions and the conditions under which it can be conceived of as a social criterion are still to be done. For instance, though Chilean researchers emphasize the role of effort rather than of talent, the former is not defined nor is there a specific operationalization of levels or measures with which assess and distinguish effort across individuals. In addition, explanations do not discuss whether the priority of effort over talent describes a particular case or reflects a more general situation in unequal societies.

Moreover, our interviews show that though scholars differ in how they view the application of the meritocratic principle, there are no clear alternatives when thinking of social criteria to allocate rewards. Even though the most negative views on meritocracy limit its extension or deny its validity, competing criteria are not easily identified. This way, it remains unclear how to challenge the predominance of inequality of opportunity and weak social mobility.

At a more general level, the lack of clarity and consensus regarding merit and meritocracy stands in contrast to their high support in public opinion (UNDP, 2017). Merit and meritocracy do not have a single definition and such different notions involve diverse social values and public policy requirements. Therefore, the emphasis on effort, which has begun to appear in recent works in 
Chilean debate (e.g. Araujo \& Martuccelli, 2014), should be further elaborated comparing approaches from different disciplines.

In regard to beliefs of meritocracy, the broad variety of views and nuances -ranging from skeptical positions to those that place it as a desirable ideal- and the consensus on the negative role that high levels of persistent inequality and the concentration of privileges have should be analyzed in future studies by examining the meanings that merit acquires in the various social classes. It is relevant to keep in mind that these conclusions refer only to scholars' views, therefore whether they mirror the voices of the general population is still an open question.

A moral economy approach can contribute to exploring whether income differences that reveal an unequal social structure translate into different lay people's evaluations of meritocracy. This would allow to link the discussion to other topics suggested by the experts, such as the relationship between meritocracy and corruption, or the intersectionality of income inequalities and gender, race or poverty. Furthermore, an analysis of the moral economy of merit in different social classes could benefit from literature on redistributive preferences, in order to study if the public policy systems that acquire greater citizen justification on the level of beliefs are evaluated similarly when they are perceived in daily life.

\section{REFERENCES}

Alon, S., \& Tienda, M. (2007). Diversity, Opportunity, and the Shifting Meritocracy in Higher Education. 72(4), 487-511. doi: $10.1177 / 000312240707200401$

Araujo, K., \& Martuccelli, D. (2014). Beyond institutional individualism: Agentic individualism and the individuation process in Chilean society. Current Sociology, 62(1), 24-40. doi:10.1177/0011392113512496

Arrow, K., Bowles, S., \& Durlauf, S. (2000). Meritocracy and economic inequality. Princeton, NJ: Princeton University Press.

Atria, J. (2018). El resurgimiento de los impuestos en la sociedad chilena. En 
F. González y A. Madariaga (Eds.), La constitución social, política y moral de la economía chilena (pp. 279-310). Santiago de Chile: RIL. Barbosa, L. (2014). "Meritocracy and brazilian society. Revista de Administraçao de Empresas, 54(1), 80-85. doi:http://dx.doi. org/10.1590/S0034-759020140108

Bell, D. (1974). The coming of post-Industrial society. London: Heinemann.

Bogner, A., \& Menz, W. (2005). Expertenwissen und Forschungspraxis: die modernisierungstheoretische und die methodische Debatte um die Experten. In A. Bogner, B. Littig, \& W. Menz, Das Experteninterview (pp. 7-29). Springer Fachrnedien Wiesbaden.

Bourdieu, P. (2004). Science of Science and Reflexivity. Chicago: The University of Chicago Press.

Bourdieu, P., \& Wacquant, L. (2005). Una invitación a una sociología reflexiva. Buenos Aires: Siglo XXI.

Bowles, S. (1998). Endogenous preferences: the cultural consequences of markets and other economic institutions. Journal of Economic Literature, 36(1), 75-111.

Breen, R., \& Goldthorpe, J. H. (1999). Class inequality and meritocracy: a critique of Saunders and an alternative analysis. British Journal of Sociology, 50(1). doi:10.1111/j.1468-4446.1999.00001.x

Cabalin, C. (2014). Online and mobilized students: The use of Facebook in the Chilean student protests. Comunicar 43, XXII, 25-33. doi: 10.3916/ C43-2014-02

Daniels, N. (1978). Merit and meritocracy. Philosophy \& Public Affairs, 7(3), 206-223.

Di Caudo, M. V. (2016). Transformaciones universitarias y cupos en Ecuador: entre equidad, meritocracia y desarrollo. Nómadas, 44, 167-183.

Duru-Bellat, M., \& Tenret, E. (2012). Who's for Meritocracy? Individual and Contextual Variations in the Faith. Comparative Education Review, 56(2), 223-247.

Flores, I., Sanhueza, C., Atria, J., \& Mayer, R. (2019). Top incomes in Chile: A historical perspective on income inequality, 1964-2017. Review of 
Income and Wealth, doi: 10.1111/roiw.12441

Flores, R. (2009). Observando observadores: una introducción a las técnicas cualitativas de investigación social. Santiago: Ediciones Universidad Católica de Chile.

Goldthorpe, J. H. (2003). The myth of education-based meritocracy. Progressive Review, 10(4), 234-239. doi:10.1046/j.1468-0041.2003.00324.x

Guzmán, V., Barozet, E., \& Méndez, M. L. (2017). Legitimación y crítica a la desigualdad: una aproximación pragmática. Convergencia Revista de Ciencias Sociales, 73 , 87-112.

Iacoviello, M., \& Strazza, L. (2011). De partidocracias rígidas a meritocracias flexibles en América Latina. Daapge, 16, 51-95.

Lamont, M., Beljean, S., \& Clair, M. (2014). What is missing? Cultural processes and causal pathways to inequality. Socio-Economic Review, 12(3), 573-608. doi:10.1093/ser/mwu011

Land, H. (2006). We sat down at the table of privilege and complained about the food. Political Quarterly, 77(1), 45-60. doi:10.1111/j.1467923X.2006.00780.X

Likki, T., \& Staerklé, C. (2015). Welfare support in europe: interplay of dependency culture beliefs and meritocratic contexts. International Journal of Public Opinion Research, 27(1), 138-153. doi:10.1093/ ijpor/edu014

Mau, S. (2003). The moral economy of welfare states: britain and germany compared. Londres: Routledge.

Mauthner, N., \& Doucet, A. (2003). Reflexive Accounts and Accounts of Reflexivity in Qualitative Data Analysis. Sociology, 37(3), 413-431. doi:10.1177/00380385030373002

Méndez, M. L., \& Gayo, M. (2007). El perfil de un debate: movilidad y meritocracia. Contribuciónal estudiodelas sociedades latinoamericanas. En R. Franco, A. León, \& R. Atria (coords.), Estratificación y movilidad en América Latina. Transformaciones estructurales de un cuarto de siglo (págs. 121-157). Santiago: Lom.

Méndez, M. L., \& Gayo, M. (2018). Upper middle class social reproduction: 
Wealth, schooling, and residential choice in Chile. Cham: Palgrave Macmillan.

Miller, D. (1999). Principles of social justice. Cambridge, MA.: Harvard University Press.

Milner, R., \& Howard, T. C. (2004). Black teachers, black students, black communities, and Brown: Perspectives and insights from experts. The Journal of Negro Education, 73(3), 285-297.

Otero, G. (2017). Formas de autoridad en la práctica científica chilena: el caso de la astronomía. Polis , 47 , 281-308.

Parrado, S.,\&Salvador,M.(2011).TheinstitutionalizationofmeritocracyinLatin American regulatory agencies. International Review of Administrative Sciences, 77(4), 687-712. doi:10.1177/0020852311419386

Pérez Sáinz, J. P. (2014). Mercados y Bárbaros. La persistencia de las desigualdades de excedente en América Latina. San José: Flacso.

Reimers, F. (2000). ¿Pueden aprender los hijos de los pobres en las escuelas de América Latina? Revista Mexicana de Investigación Educativa, 5(9), 11-69.

Reygadas, L. (2008). La apropiación. Destejiendo las redes de la desigualdad. Barcelona: Anthropos/UAM.

Rojas, X. (2008). Reflexiones sobre la construcción de la percepción de exclusión social en jóvenes de enseñanza media: precisiones conceptuales y metodológicas. Última Década, 29 , 71-99.

Rosanvallon, P. (2013). The society of equals. Cambridge, Massachusetts: Harvard University Press.

Sachweh, P. (2012). The moral economy of inequality: popular views on income differentiation, poverty and wealth. Socio-Economic Review, 10, 419-445. doi:10.1093/ser/mwr023

Saunders, P. (1995). Might Britain be a meritocracy? Sociology, 29(1), 23-41. doi: $10.1177 / 0038038595029001003$

Somma, N. (2012). The Chilean student movement of 2011-2012: challenging the marketization of education. Interface: a journal for and about social movements 4(2): 296-309. 
Son Hing, L. S., Bobocel, D. R., Zanna, M. P., Garcia, D. M., \& Gee, S. S. (2011). The merit of meritocracy. Journal of Personality and Social Psychology, 101(3), 433-450. doi:10.1037/a0024618

Telg, R. (1996). Skills and knowledge needed by television production specialists in distance education. Educational Technology Research and Development, 44(3), 73-81.

Thompson, E. (1971). The moral economy of the english crowd in the eighteenth century. Past \& Present, 50, 76-136. doi:10.1093/past/50.1.76

UNDP. (2017). Desiguales. Órigenes, cambios y desafios de la brecha social en Chile. Santiago: Uqbar.

Young, M. (1958). The rise of meritocracy. Baltimore: Peguin Books. 